\title{
Effectiveness of Sweet Orange Peel Extract (Citrus sinensis) on the Improvement of Liver Functions of Animal Trials Induced by Cigarette Smoke
}

\author{
Ika Setyawati*, Riska Anggraeni \\ Faculty of Medicine and Health Science, Universitas Muhammadiyah, Yogyakarta, Bantul, INDONESIA.
}

\begin{abstract}
Objective: Cigarette smoke contains harmful substances such as molecular compounds, reactive oxygen and nicotine compounds that can increase levels of Serum Glutamate-Pyruvate Transaminase (SGPT) and Serum Glutamic Oxaloacetic Transaminase (SGOT). Sweet orange peel extract is known to have good radical antioxidative potential and a hepatoprotective effect. This study purpose to know the effectiveness of sweet orange peel extract (Citrus sinensis) to improve the liver function of trials animal that induced by cigarette smoke. Methods: This research is experimental laboratory with pre-test and post-test with control group design. The research subjects were 25 white rats (Rattus novergicus) male Wistar strain that divided into 5 groups: P1 (negative control), P2 (positive control), P3 (sweet orange peel extract dose of $37,5 \mathrm{mg} / \mathrm{kgBW}$ ), P4 (sweet orange peel extract dose of $75 \mathrm{mg} / \mathrm{kgBW}$ ), P5 (sweet orange peel extract dose of $112,5 \mathrm{mg} / \mathrm{kgBW}$ ). The differences in SGOT-SGPT levels of pre-test and posttest were conducted by Wilcoxon test. The inhibition of increased levels of SGOT-SGPT to determine the effectiveness of sweet orange extract to the improvement of liver function using Kruskal-Wallis test. Results: Significant differences and inhibition of increase of SGOT-SGPT level $(p=0,00)$. The most effective sweet orange peel extract inhibits elevated levels of
\end{abstract}

SGOT-SGPT is group P5 (sweet orange peel extract dose of $112,5 \mathrm{mg} / \mathrm{kgBW}$. Conclusion: The sweet orange peel extract (Citrus sinensis) can effectively improve the liver function of trials animal induced by cigarette smoke.

Key words: Sweet orange peel extract (Citrus sinensis), Liver function, Serum Glutamic Oxaloacetic Transaminase, Serum Glutamate-Pyruvate Transaminase, Cigarette smoke, Rattus novergicus.

Key Message: This study is original research to investigated effectiveness of sweet orange peel extract (Citrus sinensis) on the improvement of liver functions of animal trials induced by cigarette smoke

\section{Correspondence}

Ika Setyawati, Faculty of Medicine and Health Science, Universitas Muhammadiyah Yogyakarta, Bantul, INDONESIA.

Phone: +6281392201984

Email: dr.ikasetyawati@yahoo.co.id, icapps2017.farmasiui@gmail.com

DOI: 10.5530/jyp.2018.2s.27

\section{INTRODUCTION}

Smoking has many harmful effects on health and has hepatotoxic effects. ${ }^{1}$ Cigarette smoke is form of free radicals. Free radicals are produced in the human bodies which cause different disorders such as liver injury. ${ }^{2}$ Cigarette smoke is can increase the levels of Serum Glutamate-Pyruvate Transaminase (SGPT), Serum Glutamic Oxaloacetic Transaminase (SGOT), and Alkaline Phosphatase (ALP) in the liver and may decrease endogenous antioxidant levels. ${ }^{3-4}$ It is caused by cigarette smoke causes lipid peroxidation that damages hepatic cell membrane serum aminotransferase enzyme (sensitive enzyme for liver damage) will come out to the blood so that there is an increase levels of SGOT and SGPT. ${ }^{5-6}$

Sweet orange peel extract is known to have good radical antioxidative potential. ${ }^{6}$ Some researchers showed that orange peel contained phenolic compounds, flavonoids, carotenoids and anthocyanins. Flavonoids are the main content of orange peel. Flavonoids in sweet oranges there are three types of flavanones, flavones, and flavonols. The pharmacological activity of this plant also has been studied such as anti-inflammatory effects, antioxidants and hepatoprotective effects ${ }^{7-8}$ In this study, the effectiveness of sweet orange peel extract (Citrus sinensis) was examined for the hepatoprotective activity to improve the liver function

\section{MATERIALS AND METHODS}

\section{Preparation of extract}

Preparation of sweet orange peel extract was done by making simplicia. Orange is washed with water. Take the orange peel and then dried at $40^{\circ} \mathrm{C}$. Putthe dry orange peel in a blender until it becomes powder / simplicia. Simplicia is mixed with solvent in the form of ethanol $70 \%$ then macerated for $48 \mathrm{~h}$. Put the result of maceration into the rotary evaporator and the viscous extract will be obtained.

\section{Experimental animals}

White rats (Rattus novergicus) male Wistar strain (25) selected based on inclusion and exclusion criterias. Inclusion criteria; the age of rat was 2 months, weighed $\pm 200 \mathrm{~g}$, healthy looking seen from the activity of movement. Exclusion criteria; visible anatomical abnormalities of rat, looked sick and do not move actively.

\section{Experimental chemical and food}

Cigarette smoke was used for inducing liver damage in rats, two stem of cigarette smoke was administrated inhalation. Sweet orange peel were purchased from local grocery.

\section{Experimental design}

After 3 days of acclimatization period, the experimental animals were divided into five groups $(n=5)$ as follows: Group I: The animals received standar food and drinking water without tested extract and cigarette smoke for 14 days (negative control). Group II: The animals are only induced by cigarette smoke for 14 days (positive control). Group III: Cigarette smoke + sweet orange peel extract at an oral doses 


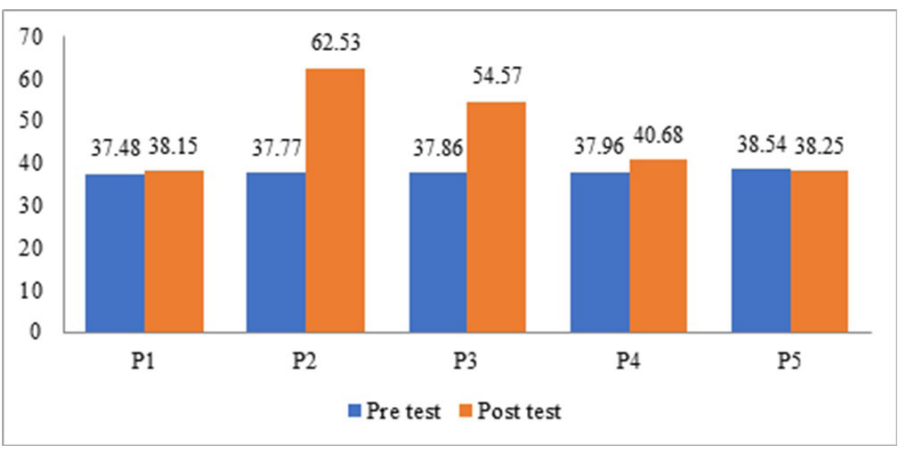

Figure 1: The comparison graph of SGOT levels in pre-test and post-test.

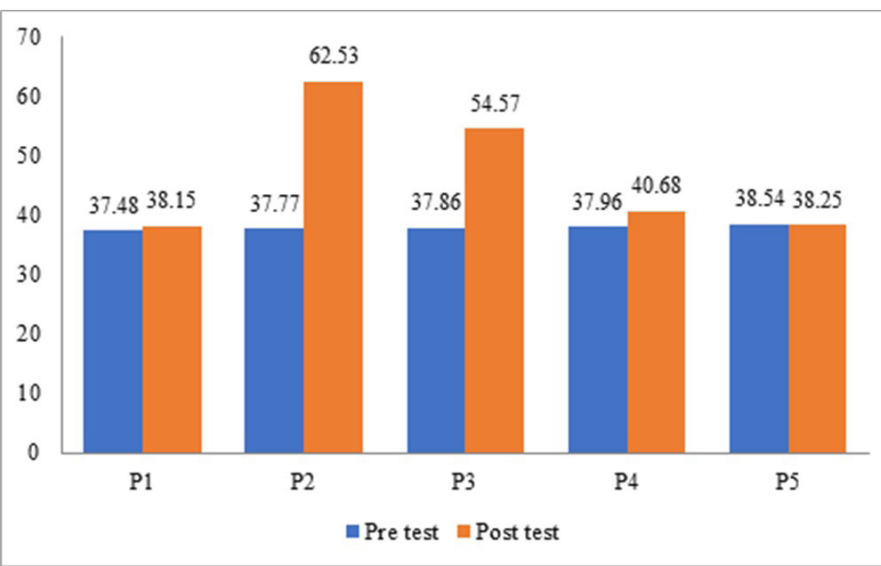

Figure 2: The comparison graph of SGOT levels in pre-test and post-test.

of $37.5 \mathrm{mg} / \mathrm{kgBW} /$ day for 14 days. Group IV: Cigarette smoke + sweet orange peel extract at an oral doses $75 \mathrm{mg} / \mathrm{kgBW} /$ day for 14 days. Group V: Cigarette smoke + sweet orange peel extract at an oral doses $112.5 \mathrm{mg} / \mathrm{kgBW} /$ day for 14 days. All treatments were only orally administered continuously using a single dose of body weight. The effect of these groups on animal liver were studied at the end of the study.

\section{Biochemical analysis}

Before and after the completion 14 days treatment, animals were fasted overnight and blood samples were collected from retro-orbital plexus. Blood samples were allowed to clot for approximately $1 \mathrm{~h}$ at room temperature and centrifuged at $3000 \mathrm{rpm}$ for $10 \mathrm{~min}$ to obtain the serum, used for estimation of various biochemical parameters such as serum glutamic oxalocetic transaminase (SGOT) and serum glutamic-pyruvic transaminase (SGPT). The activities of these biochemical parameters were determined using commercially available kits (DiaSys Diagnostic Systems GmbH and Co. KG, Germany).

\section{Statistical analysis}

Data were expressed as mean \pm SD (Standard Deviation). The statistical analysis was carried out by Wilcoxon test. The value were statistically significant at $\mathrm{p}<0.05$.

\section{RESULTS}

In the present study was investigate the improvement of liver functions of animal trials induced by cigarette smoke and sweet orange peel extract (Citrus sinensis). Extracts are simplicia were obtained by macerated process. The SGOT and SGPT levels were also determined. The level of SGOT and SGPT were determined using Optimized UV- Test according to IFCC (International Federation Of Clinical Chemistry). ${ }^{9}$
In this study, the effect of different extracts on SGOT and SGPT levels in normal rat and induced groups were evaluated. Mean difference of SGOT levels in the pre-test and post-test groups using Wilcoxon test. Table 1 shows there was a significant difference in the mean of SGOT levels pre-test and post-test in P1, P2, P3 and P4 groups. The highest increase of SGOT levels was found in group P2. The group P5 showed the mean of SGOT levels pre-test was higher than the post-test but was not statistically significant.

Table 2 shows a significant difference in the mean of SGPT levels in white rats (Rattus novergicus) pre-test and post-test in P2, P3, P4, and $\mathrm{P} 5$ groups. There was no significant difference in the mean of pretest and post test in Group P1. The highest increase of SGPT levels was found in group P2. The P5 group showed the mean SGPT pre-test level was lower than the post-test and was statistically significant.

Table 3 shows the highest difference in the mean increase of SGOT levels pre-test and post-test is group P2. The group P5 has the lowest increase in SGOT levels of all groups.

Table 4 shows the highest difference in mean increaseof SGPT levels pre-test and post-test levels is group P2. The group P5 has the lowest increase of SGPT levels compared to Group P3 and P4.

\section{DISCUSSION}

The enzymatic activity of SGOT and SGPT was studied to evaluate the presence of liver disorders. Liver enzyme levels will usually increase in acute hepatotoxicity, but tend to decrease in prolonged intoxication because there is damage to the liver. ${ }^{10}$ The liver is a central metabolizing organ so it susceptible to metabolism-dependant injury. After injury may be a direct toxic effect or immunological reaction to either the drug or an active metabolite formed by ioactivation. ${ }^{11}$

Table 1: The Average level of SGOT in White Rats (Rattus novergicus) Pretest and Posttest Induction of Cigarette Smoke and Sweet Orange Peel Extract (Citrus sinensis).

\begin{tabular}{cccc}
\hline \multirow{2}{*}{ Group } & \multicolumn{2}{c}{ SGOT Level (U/I) \pm SD } & \multirow{2}{*}{$\begin{array}{c}\text { P value (Wilcoxon } \\
\text { test) }\end{array}$} \\
\cline { 2 - 3 } & Pre test & Post test & 0,041 \\
\hline P1 & $37,48 \pm 0,63$ & $38,15 \pm 0,55$ & 0,042 \\
P2 & $37,77 \pm 0,63$ & $62,53 \pm 0,63$ & 0,043 \\
P3 & $37,86 \pm 0,76$ & $54,57 \pm 1,00$ & 0,042 \\
P4 & $37,96 \pm 0,40$ & $40,68 \pm 0,63$ & 0,414 \\
P5 & $38,54 \pm 1,00$ & $38,25 \pm 0,40$ & \\
\hline
\end{tabular}

Data were expressed as mean \pm SD (Standard Deviation). Data was significantly different if $\mathrm{p}$ value $<0,05$.

Table 2: The mean of SGPT levels in white rats (Rattus novergicus) Pre test and Post test Induction of Cigarette Smoke and Sweet Orange Peel Extract (Citrus sinensis).

\begin{tabular}{cccc}
\hline \multirow{2}{*}{ Group } & \multicolumn{2}{c}{ SGPT Level $(\mathrm{U} / \mathrm{I}) \pm$ SD } & P value (Wilcoxon test) \\
\cline { 2 - 4 } & Pre test & Post test & \\
\hline P1 & $18,15 \pm 0,55$ & $18,35 \pm 0,40$ & 0,414 \\
P2 & $18,25 \pm 0,26$ & $38,45 \pm 0,63$ & 0,042 \\
P3 & $18,44 \pm 0,34$ & $29,13 \pm 0,34$ & 0,041 \\
P4 & $18,15 \pm 0,55$ & $25,44 \pm 0,73$ & 0,042 \\
P5 & $18,54 \pm 0,79$ & $20,68 \pm 0,94$ & 0,043 \\
\hline
\end{tabular}

Data were expressed as mean \pm SD (Standard Deviation). Data was significantly different if $\mathrm{p}$ value $<0,05$. 
Table 3: The Difference in the mean increase of SGOT levels in White Rats (Rattus novergicus) Pretest and Posttest Induction of Cigarette Smoke and Sweet Orange Peel Extract (Citrus sinensis)

\begin{tabular}{ccc}
\hline Group & $\begin{array}{c}\text { Mean Increase of SGOT } \pm \text { SD } \\
(\mathrm{U} / \mathrm{l})\end{array}$ & P value (Kruskal-Wallis Test) \\
\hline P1 & $0,67 \pm 0,43$ \\
P2 & $24,76 \pm 0,68$ \\
P3 & $16,70 \pm 1,51$ & 0,00 \\
P4 & $2,71 \pm 0,73$ \\
P5 & $-0,29 \pm 0,94$ \\
\hline Data were expressed as mean \pm SD (Standard Deviation). Data was significantly different if P value $<0,05$.
\end{tabular}

Table 4: The Differences in the mean increase of SGPT levels in White Rats (Rattus novergicus) Pretest and Posttest Induction of Cigarette Smoke and Sweet Orange Peel Extract (Citrus sinensis)

\begin{tabular}{ccc}
\hline Group & $\begin{array}{c}\text { Mean Increase of } \\
\text { SGPT } \pm \text { SD }(\mathrm{U} / \mathrm{l})\end{array}$ & P value (Kruskal-Wallis Test) \\
\hline P1 & $0,19 \pm 0,55$ \\
P2 & $20,19 \pm 0,88$ \\
P3 & $10,68 \pm 0,59$ & 0,00 \\
P4 & $7,28 \pm 0,97$ \\
P5 & $2,13 \pm 1,00$ \\
\hline Data were expressed as mean \pm SD (Standard Deviation). Data was significantly different if $p$ value $<0,05$.
\end{tabular}

The evaluation of the improvement of liver functions of animal trials induced by cigarette smoke had been widely used for hepatoprotective drug screening. Cigarette smoke is used experimental hepatotoxicant which decreased of antioxidan activity, increased of oxidative stress and initiating lipid peroxidation thus causing damage to cell membrane. Lipid peroxidation occurs on polysaturated fatty acid located on the cell membranes and it further proceeds with radical chain reaction. Hydroxyl radical is thought to initiate ROS and remove hydrogen atom, thus producing lipid radical and further converted into diene conjugate. Further, by addition of oxygen it forms peroxyl radical; this highly reactive radical attacks another fatty acid forming lipid hydroperoxide (LOOH) and a new radical. Thus lipid peroxidation is propagated. ${ }^{12}$ This peroxidative degradation of the liver cell plasma membrane, leads to the release of a variety of enzymes (SGOT, SGPT) normally located in the cytosol into the blood stream, and estimating the activities of these serum marker enzymes can make the assessment ot liver function. ${ }^{5}$

Phytochemical are usually recognized as antioxidant with contain flavonoid. In current findings, it was confirmed that flavonoids are present in sweet orange peel extract (Citrus sinensis), which are responsible for scavenging free radicals. ${ }^{13}$

The hepatoprotective effect of sweet orange peel extract (Citrus sinensis) was performed by testing the SGOT-SGPT levels in the blood plasma of trials animal. The enzymatic activity of SGOT-SGPT was studied to evaluate disorders in the liver. Hepatic enzyme levels will increase in acute hepatotoxicity, but tend to decrease in prolonged intoxication because of damage to hepar. ${ }^{9}$

The results of this study showed that the highest mean increased level of SGOT-SGPT pre test and post test was found in group P2 (treatment of cigarette smoke induction without sweet orange peel extract) with $p$ value $=0,042$ (Table 1 and 2 ). This is in accordance with the research of Omotoso et al. 2012 showed the increasing of SGOT-SGPT levels in Wistar rats in cigarette smoke induction was higher than those in cotton smoke induction. Cigarette smoke increases levels of SGOT, SGPT and ALP that are able to stimulate changes in the liver membrane permeability trait and decrease antioxidant activity of glutathione thus causing more hepatotoxicity in hepatic tissue. ${ }^{1}$
The study by Alsalhen (2014) also showed that there was an increase in SGOT and SGPT levels in heavy smokers compare with the group Control $(\mathrm{p}<0.05)$. Cigarette smoke causes lipid peroxidation that damages cell membranes in the liver. Damage to hepatic cells will increase levels of amino transferase resulting in increased levels of SGOT and SGPT. ${ }^{5-6}$

The study by Kumar (2015) also showed that smoking can increase levels of SGOT and SGPT. ${ }^{14}$ Decreased plasma protein in smokers is a bad effect of harmful compounds of cigarettes on liver cells. This is indicated by the increase of SGOT and SGPT. Decreased plasma proteins are due to protein loss due to decreased protein synthesis or an increase in proteolytic activity caused by exposure to second hand smoke. ${ }^{5}$

The results of this study showed that the most effective dose as a hepatoprotector is sweet orange peel extract (Citrus sinensis) with a dose of $112.5 \mathrm{mg} / \mathrm{kgBW}$ because the lowest difference that found in increased SGOT-SGPT levels before and after treatment, $\mathrm{p}=0.00$ (Table 3 and 4). This result is appropriate like the study of pantsulaia et al. In 2014 in two dosage groups of orange peel extract (75 mg / kgBW and $150 \mathrm{mg} / \mathrm{kgBW}$ ) it was found that the dose of orange peel extract that having protective effect on the liver was $75 \mathrm{mg} / \mathrm{kgBW}$ dose. Group dose of orange peel extract $150 \mathrm{mg} / \mathrm{kgBW}$ was not found inhibition of increased SGOT and SGPT due to the emergence of side effects or toxic effects on the dose. ${ }^{8}$

This study showed that cigarette induced rats groups had higher SGOTSGPT levels than non-induced cigarette rats, while the treated group (smoke induction + sweet orange peel extract) SGOT-SGPT levels were lower than those in only given the induction of cigarette smoke.

\section{CONCLUSION}

We conclude that the sweet orange peel extract (Citrus sinensis) may inhibit the increase of SGOT-SGPT levels of cigarette induced rats and effectively improve the liver function of trials animals induced by cigarette smoke.

\section{ACKNOWLEDGEMENT}

We would like to thank Lembaga Pengembangan Pendidikan, Penelitian dan Masyarakat (LP3M) Universitas Muhammadiyah Yogyakarta for support the research. 


\section{CONFLICT OF INTEREST}

The authors declare no conflict of interest.

\section{ABBREVIATIONS}

ALP: Alkaline Phosphatase; IFCC: International Federation of Clinical Chemistry; SGOT: Serum Glutamic Oxaloacetic Transaminase; SGPT: Serum Glutamate-Pyruvate Transaminase.

\section{SUMMARY}

This Study shows that sweet orange peel extract (Citrus sinensis) is effective to improve liver functions of animal trials by cigarette smoke. Parameter livers functions in this study are SGOT-SGPT levels. The most effective dose of Citrus sinensis as a hepatoprotector is $112.5 \mathrm{mg} / \mathrm{kgBW}$.

\section{REFERENCES}

1. Omotoso GO. Lipid profile and liver histochemistry in animal models exposed to cigarette smoke. J Basic Appl Sci. 2012;8(1):20-5.

2. Gogoi N, Gogoi A, Neog B, Baruah D, Singh KD. Evaluation of antioxidant and hepatoprotective activity of fruit rind extract of Garcinia dulcis (Roxburgh) Kurz. Phcog Res. 2017;9(3):266-72.

3. Johnston DE. Special considerations in interpreting liver function tests. Am Fam Physician. 1999;59(8):2223-30.

4. El-Zayadi A, Selim O, Hamdy H, El-Tawil A, Badran HM, Attia M, et al. Impact of cigarette smoking on response to interferon therapy in chronic hepatitis C Egyptian patients. World J Gastroenterol. 2004;10(20):2963-6.

5. Alsalhen KS, Abdalsalam RD. Effect of cigarette smoking on liver functions: A comparative study conducted among smokers and non-smokers male in El-beida City, Libya. Int Curr Pharm J. 2014;3(7):291-5.

6. Woreta TA, Alqahtani SA. Evaluation of abnormal liver tess. Med Clin North Am. 2014;98(1):1-16.

7. Hegazy AE, Ibrahium MI. Antioxidant activities of orange peel extracts. WASJ 2012;18(5):684-8.

8. Pantsulaia la, lobadze M, Pantsulaia N, Chikovani T. The effect of citrus peel extracts on cytokines levels and T regulatory cells in acute liver injury. Biomed Res Int. 2014:2014:127879.

9. Mahmud ZA, Bachar SC, Qais N. Antioxidant and hepatoprotective activities of ethanolic extracts of leaves of Premna esculenta roxb. Against carbon tetrachloride-induced liver damage in rats. J Young Pharm. 2012;4(4):228-34.

10. Imafidon KE, Okunrobo LO. Study on biochemical indices of liver function tests of Albino rats supplemented with three sources of vegetable oils. Nig J Basic Appl Sci. 2012;20(2)105-10. Vaghasiya J, Rathod S, Bhalodia Y, Manek R, Malaviya S, Jivani N. Protective Effect of Polyherbal Formulation on Simvastatin Hepatotoxicity in Rats. J Young Pharm. 2009;1(1):57-62.

11. Kumar S, Mahat RK, Batra J. Evaluation of lipid parameters, liver function test, CRP and MDA (as a marker of lipid peroxidation) in chronic cigarette smokers. IJBAR. 2015;115-9.

12. Erukaine OL, Ajiboye JA, Davis FF, Obabire K, Aliyu M. Effect of Orange (Citrus sinensis) Peel oil on Lipid Peroxidation, Catalase activity and Hepatic Biomarker levels in Blood Plasma of Normo Rats. JBPR. 2012;1(1):16-23.

13. Lobo V, Patil A, Phatak A, Chandra N. Free radicals, antioxidants and functional foods: Impact on human health. Phcog Rev. 2010;4(8):118-26.

Article History: Submission Date : 18-01-2018 ; Revised Date : 10-02-2018; Acceptance Date : 12-04-2018.

Cite this article: Setyawati I, Anggraeni R. Effectiveness of Sweet Orange Peel Extract (Citrus sinensis) on The Improvement of Liver Functions of Animal Trials Induced by Cigarette Smoke. J Young Pharm. 2018;10(2)Suppl:s132-s135. 